University of Wollongong

Research Online

Faculty of Engineering and Information

Faculty of Engineering and Information

Sciences - Papers: Part A

Sciences

$1-1-2014$

Performance assessment of reinforced ballasted rail track

Buddhima Indraratna

University of Wollongong, indra@uow.edu.au

Sanjay Nimbalkar

University of Wollongong, sanjayn@uow.edu.au

Tim Neville

Australian Rail Track Corporation Ltd

Follow this and additional works at: https://ro.uow.edu.au/eispapers

Part of the Engineering Commons, and the Science and Technology Studies Commons

Research Online is the open access institutional repository for the University of Wollongong. For further information contact the UOW Library: research-pubs@uow.edu.au 


\title{
Performance assessment of reinforced ballasted rail track
}

\begin{abstract}
In coastal Australia, high population density and increased traffic volumes have promoted rapid expansion of urban transportation infrastructure including railways. Coastal soft clays pose significant construction challenges. Therefore, the search for innovative ground improvement techniques imperative for more resilient and sustainable transport infrastructure has become an obvious priority in research and development. Use of artificial inclusions such as polymeric geosynthetics and energy-absorbing shock mats is described in this paper as a suitable alternative for reducing unacceptable track degradation and for ensuring sustainable track alignment. An extensive monitoring programme was undertaken on fully instrumented track sections constructed near Singleton, New South Wales, Australia. Four types of geosynthetics were installed at the ballast-capping interface of track sections located on different types of subgrades. It was found that geogrids could decrease the vertical settlement of the ballast layer with the obvious benefits of improved track stability and decreased cost of maintenance. It was also found that the effectiveness of reinforcing geogrids is greater when the subgrade is soft.
\end{abstract}

\section{Keywords}

Field testing \& monitoring, geotextiles, membranes \& geogrids, railway systems

Disciplines

Engineering | Science and Technology Studies

\section{Publication Details}

Indraratna, B., Nimbalkar, S. \& Neville, T. (2014). Performance assessment of reinforced ballasted rail track. Proceedings of the ICE: Ground Improvement, 167 (1), 24-34. 


\section{Performance assessment of reinforced ballasted rail track}

Buddhima Indraratna MSC, DIC, PhD

Professor of Civil Engineering, Centre for Geomechanics and Railway Engineering, University of Wollongong, Wollongong City, NSW, Australia

Sanjay Nimbalkar BEng, MTech, PhD

Research Fellow, Centre for Geomechanics and Railway Engineering, University of Wollongong, Wollongong City, NSW, Australia
Tim Neville BEng

Senior Geotechnical Engineer, Australian Rail Track Corporation Ltd, Broadmeadow, NSW, Australia

In coastal Australia, high population density and increased traffic volumes have promoted rapid expansion of urban transportation infrastructure including railways. Coastal soft clays pose significant construction challenges. Therefore, the search for innovative ground improvement techniques imperative for more resilient and sustainable transport infrastructure has become an obvious priority in research and development. Use of artificial inclusions such as polymeric geosynthetics and energy-absorbing shock mats is described in this paper as a suitable alternative for reducing unacceptable track degradation and for ensuring sustainable track alignment. An extensive monitoring programme was undertaken on fully instrumented track sections constructed near Singleton, New South Wales, Australia. Four types of geosynthetics were installed at the ballast-capping interface of track sections located on different types of subgrades. It was found that geogrids could decrease the vertical settlement of the ballast layer with the obvious benefits of improved track stability and decreased cost of maintenance. It was also found that the effectiveness of reinforcing geogrids is greater when the subgrade is soft.

\section{Notation}

A shift in particle size distribution (PSD) curve

$A_{\mathrm{t}} \quad$ axle load (tonne)

$a \quad$ aperture size of geogrids ( $\mathrm{mm})$

$a^{\prime}, b^{\prime} \quad$ empirical constants relating deformation and the logarithm of load cycles

$B \quad$ potential breakage or area between arbitrary boundary of maximum breakage and final PSD

$c^{\prime}, d^{\prime} \quad$ empirical constants relating vertical strain and the logarithm of load cycles

$d_{\max } \quad$ maximum particle size $(\mathrm{mm})$

$d_{\min } \quad$ minimum particle size $(\mathrm{mm})$

$d_{50} \quad$ particle size at percent finer of 50\% $(\mathrm{mm})$

$d_{95 \mathrm{i}} \quad$ particle size at percent finer of $90 \%(\mathrm{~mm})$ of $d_{\max }$

$N \quad$ number of load cycles

$N_{\mathrm{a}} \quad$ number of axles per load cycle

$S_{\mathrm{V}} \quad$ vertical deformation of ballast layer $(\mathrm{mm})$

$S_{\mathrm{tv}} \quad$ transient vertical deformation of ballast layer (mm)

$S_{\mathrm{th}} \quad$ transient horizontal deformation of ballast layer $(\mathrm{mm})$

$T \quad$ total traffic tonnage (tonne)

$\varepsilon_{\mathrm{gt}} \quad$ cumulative transverse strain in geogrids or geocomposites (\%)

$\varepsilon_{\mathrm{gl}} \quad$ cumulative longitudinal strain in geogrids or geocomposites (\%)

$\varepsilon_{\text {th }} \quad$ transient average horizontal strain of ballast layer (\%)

$\varepsilon_{\mathrm{tv}} \quad$ transient vertical strain of ballast layer (\%)

$\varepsilon_{\mathrm{tt}} \quad$ transient transverse strain in geogrids or geocomposites (\%)

$\begin{array}{ll}\varepsilon_{\mathrm{tl}} & \begin{array}{l}\text { transient longitudinal strain in geogrids or } \\ \text { geocomposites }(\%)\end{array} \\ \varepsilon_{\mathrm{v}} & \text { vertical strain of ballast layer }(\%) \\ \sigma^{\prime} & \text { traffic-induced vertical stress }(\mathrm{kPa}) \\ \sigma_{\mathrm{v}}^{\prime} & \text { vertical stresses }\end{array}$

\section{Introduction}

Ballasted rail tracks serve as one of the major infrastructures for freight and passenger transport in Australia. In recent years, an increasing demand for such transport has led to the use of considerably heavier and faster trains. Large cyclic stresses from train traffic can induce rapid deformations and degradation of the ballast layer (Indraratna et al., 2011b; Lackenby et al., 2007; McDowell and Harireche, 2002). This, in turn, adversely affects track stability and increases the frequency of track maintenance.

It has been observed from several laboratory studies (Chen et al., 2012; Indraratna and Nimbalkar, 2013; Indraratna et al., 2007; McDowell et al., 2006; Rowe and Jones, 2000; Shin et al., 2002) that layers of geosynthetics when placed in the track substructure can increase the stability and therefore the longevity of ballasted rail tracks. Nevertheless, only a few studies have investigated the benefits of geosynthetic reinforcement under 'field' conditions. Among these studies, Indraratna et al. (2010) performed a field trial on a track, in which layers of geocomposite (combination of biaxial geogrids and non-woven polypropylene geotextiles) were installed at the ballast-capping interface. They reported a reduction of up to $40 \%$ in vertical and horizontal strains of the ballast layer for the reinforced track section. 
The aperture size of geogrids in relation to the mean particle size of the ballast mainly governs the effectiveness of the reinforcement mechanism. McDowell et al. (2006) recommended the ratio between grid aperture size and nominal size of the aggregate to be 1.4, whereas Brown et al. (2007) recommended this ratio to be $1.2-1.6$ for minimising the settlement of ballast employed in the UK (Railtrack, 2000). In view of rail industry practices in Australia (Standards Australia, 1996), this ratio was proposed to be 1.15-1.3 for optimising the shear strength (Indraratna et al., 2011a). However, there is a lack of sufficient knowledge of how geogrids interact with ballast particles when subjected to the stress and strain environment resulting from moving wheel loads.

A stiff track structure (e.g. concrete bridges and tunnels) can create severe dynamic loading under operating conditions, leading to large-scale failure of components and a subsequent increase in maintenance. Installing resilient mats, such as rubber pads (shock mats) in rail tracks can attenuate the dynamic forces and improve overall performance. A shock mat is called an 'under ballast mat' (UBM) when provided below the ballast layer, and an 'under sleeper pad' (USP) when provided below the sleeper. Recently, the use of USPs has increased as they reduce dynamic stresses and vibrations in high-speed railway tracks (Esveld, 2009; Ferreira and LópezPita, 2013). The ability of UBMs to reduce structural noise, vibration (Anastasopoulos et al., 2009; Auersch, 2006) and ballast breakage (Indraratna et al., 2012; Nimbalkar et al., 2012) has been studied extensively. Minimising ballast degradation is imperative to sustain its primary functions and the overall working of the substructure.

The field performance of different geosynthetics used as reinforcing elements for ballasted tracks, and the use of UBMs for mitigating particle degradation has not been investigated in a systematic manner. The present study was undertaken to fill this gap. Fully instrumented track sections were constructed near the city of Singleton, New South Wales, Australia. Permanent and transient strains of ballast, breakage of particles and variation of vertical stresses in the track substructure were routinely monitored. The details of an experimental programme as well as field monitoring results of this study are presented herein

\section{Experimental track sections}

\subsection{Site layout and subsurface exploration}

The experimental track sections were part of the Minimbah Bank Stage 1 Line that extended from Bedford (chainage $224.2 \mathrm{~km}$ ) to Singleton $(235.06 \mathrm{~km})$. The location of the instrumented test track was about $200 \mathrm{~km}$ from Sydney, New South Wales, Australia. A subsurface exploration programme indicated that the rail track was located on an extensive medium- to high-strength siltstone outcrop between 224.2 and $229.0 \mathrm{~km}$ and on the flood plain of the nearby Hunter River thereafter (RCA, 2008). The flood plain consisted of a layer of alluvial silty clay deposit $7-$ $10 \mathrm{~m}$ thick underlain by heterogeneous layers of medium dense sand and silty clay with a total thickness of 7-9 m. Mediumstrength siltstone was found beneath the sand-silty clay layer.

\subsection{Track construction}

The track substructure consisted of a ballast layer which extended about $300 \mathrm{~mm}$ below sleepers. It was underlain by a 150$300 \mathrm{~mm}$ thick capping layer. A structural fill layer of 400$600 \mathrm{~mm}$ thickness was placed below the capping layer. The thickness of the structural fill was varied depending on the type of subgrade, and the thickness of the capping layer was commensurate with that of the structural fill in order to satisfy the minimum track formation depths as specified by the adopted construction provisions (ARTC, 2007b). Eight experimental sections were included in the track at the time of construction. Figure 1 shows the locations of experimental sections on different parts of the rail track. These experimental sections were located on subgrades, namely (a) the relatively soft general fill and alluvial silty clay deposit (sections 1-4 and A), (b) the intermediate siltstone (sections 5 and $\mathrm{C}$ ) and (c) the stiff reinforced concrete bridge deck (section B). This was carried out to study the effects of varying the subgrade type on the performance of geosynthetic reinforcement. Figure 2 shows the details of the geosynthetics and UBM placement locations at the trial sections. Single layers of three types of geogrids were installed in sections $1-3$ and 5, and a layer of geocomposite was installed at section 4 to study their

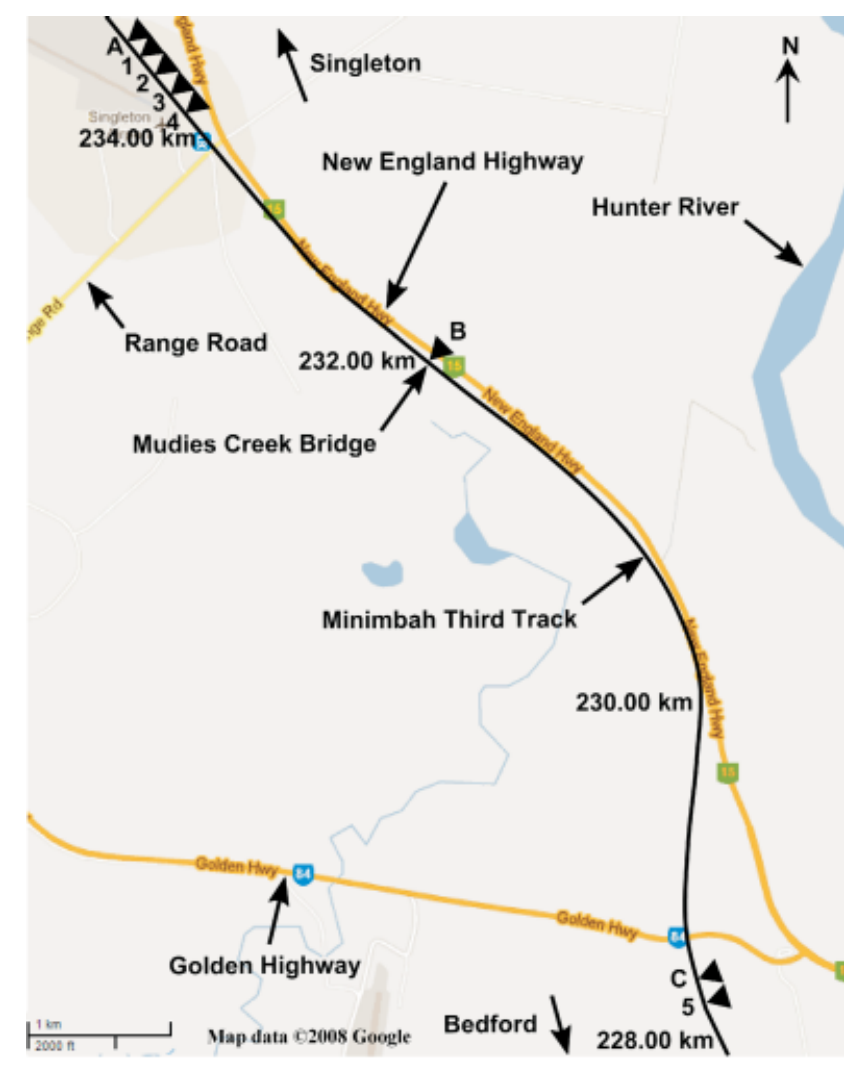

Figure 1. Locations of instrumented track sections at Singleton (data sourced from RCA, 2008) 


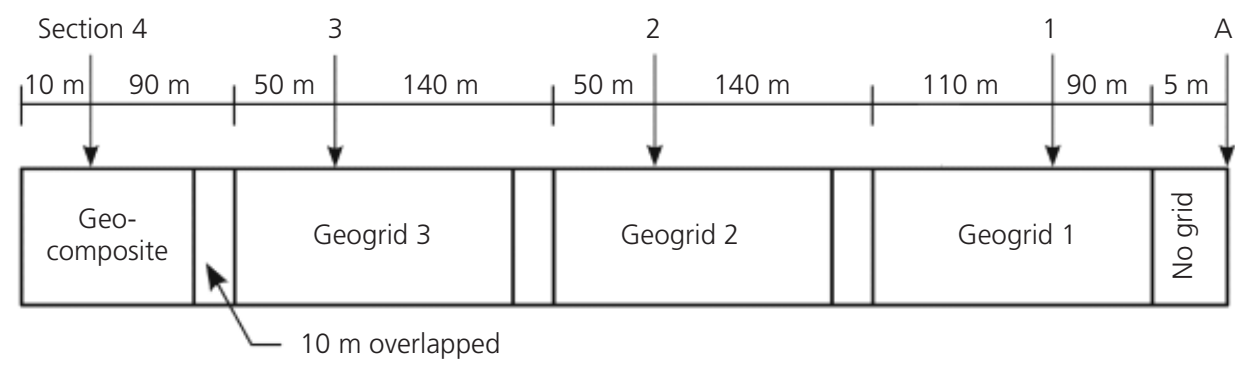

(a)

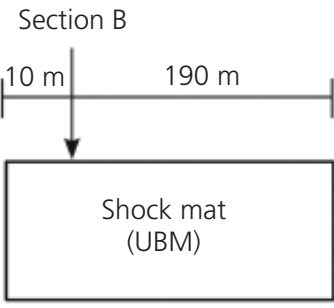

(b)

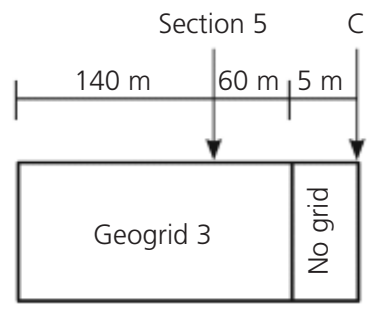

(c)

Figure 2. Reinforcement of track substructure with different

geosynthetics at (a) sections A to 4, (b) section B, and

(c) sections 5 and $C$

potential benefits for improving the overall track stability. These geosynthetic reinforcing materials were installed at the ballastcapping interface, as in actual practice the depth of this placement (about $300 \mathrm{~mm}$ from the base of the sleeper) is adequate to prevent any damage from the tamper tines. For comparison purposes, no geosynthetic was installed at sections A and C. A layer of UBM was installed at the ballast-deck interface at section B (Figure 2(b)) to minimise particle degradation.

\subsection{Material specifications}

\subsubsection{Ballast and capping characteristics}

The particle gradations of the ballast and capping were in accordance with the construction provisions (ARTC, 2006a, 2006b, 2007a) and are shown in Figure 3. The particle gradation and USCS classification of these materials (at the time of track commission) are reported in Table 1. The ballast consisted of compacted highly angular latite basalt particles. The underlying capping layer was compacted sandy gravel. The percentage of silt and clay-sized particles (by weight) of the capping was $10 \%$. The ballast and capping were obtained from the same quarry (Allandale, $20 \mathrm{~km}$ north-west of Singleton) and comprised similar mineral components.

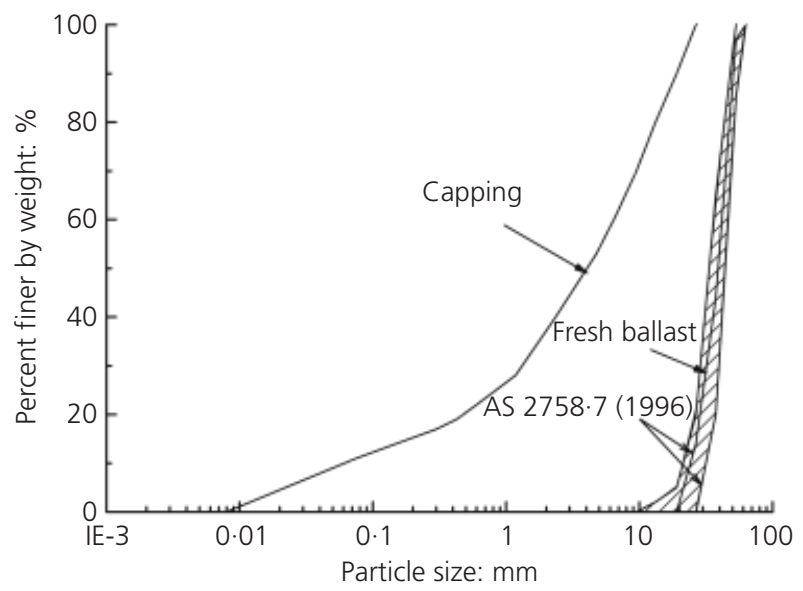

Figure 3. Particle gradations of fresh ballast and capping used in construction of track

\subsubsection{Geosynthetics and UBM characteristics}

Four types of geosynthetics, namely three biaxial geogrids and one geocomposite (biaxial geogrid + non-woven geotextile), were used to stabilise the railway ballast. The biaxial geogrids were 


\begin{tabular}{|c|c|c|c|c|c|c|}
\hline Material & Description & $d_{\max }: m m$ & $d_{\min }: m m$ & $d_{50}: \mathrm{mm}$ & $\begin{array}{c}\text { USCS } \\
\text { classification }\end{array}$ & $\begin{array}{c}\text { California } \\
\text { bearing ratio } \\
(\mathrm{CBR}): \%\end{array}$ \\
\hline Fresh ballast & Compacted angular latite basalt & 63 & 19 & 36 & GP & - \\
\hline Capping & Compacted sandy gravel & $26 \cdot 5$ & 0.008 & 4 & GP-GM & 50 \\
\hline
\end{tabular}

Table 1. Grain size characteristics and USCS classification of ballast and capping materials

made of polypropylene, and were generally suitable for soil stabilisation and reinforcing applications because of their high tensile strength and high tensile stiffness. Adding a non-woven geotextile to the biaxial geogrid enabled the geocomposite to provide filtration, separation and partial in-plane drainage (Indraratna et al., 2007; Indraratna and Nimbalkar, 2013). The UBMs (elastic pads or rubber mats) had high impact strength and are typically installed as a protective layer over several bridges in Australia. The UBMs are composed of bonded rubber granulates with typical particle sizes between 1 and $3 \mathrm{~mm}$ with polyurethane elastomer binding. Table 2 lists the physical, strength and dimensional characteristics of these materials as employed in this study.

\section{Track instrumentation}

\subsection{Pressure cells}

Traffic-induced vertical stresses in the track were monitored by pressure cells that were suitable to measure compressive stresses up to $600 \mathrm{kPa}$. Two pressure cells were installed at sections 1,5 , $\mathrm{A}$ and $\mathrm{C}$ (Figure 4(a)). One pressure cell was installed at the sleeper-ballast and another at the ballast-capping interface. At section $\mathrm{B}$, however, three pressure cells were installed at the UBM-deck interface. Two cells were located below the up rail, whereas the other was below the down rail.

\subsection{Strain gauges}

Strain gauges were used to study longitudinal and transverse strains accumulated in the geogrid layers. The strain gauges were of post-yield type and suitable to measure strains in the range of $0 \cdot 1$ to $15 \%$. They were installed in a group, on the top and bottom sides of grids in both longitudinal and transverse directions (Figure 4(b)).

\subsection{Settlement pegs}

Settlement pegs were installed to monitor vertical deformation of the ballast layer. The settlement pegs were installed at the sleeper-ballast and ballast-capping interfaces (Figure 4(c)). A simple survey technique was used to track the movements of pegs and deformations of the ballast layer were later determined.

\subsection{Displacement monitoring frame}

Transient deformations of the ballast layer were measured by electronic potentiometers (POTs) mounted on a custom-made aluminium frame as shown in Figure 4(d). Two POTs - one monitoring the vertical movement of sleepers another for that of the ballast-capping pegs - determined the transient vertical displacements of the ballast layer. The other three POTs mounted in an inclined fashion monitored both vertical and horizontal deformations of the ballast shoulder at different locations. The deformation frame was used at all experimental sections, except at section B. The frame was held in place by support bases installed in the capping and structural-fill layers (i.e. more than $150 \mathrm{~mm}$ depth).

\subsection{Data acquisition}

Data from the pressure cells, strain gauges and POTs as well as levels of the settlement pegs were obtained immediately after the instruments were installed. Subsequently, the data were obtained daily for three days, weekly for three weeks, monthly for three months and then quarterly for three quarters.

\section{Field monitoring results}

The ballast deformation and strains in geogrids were measured against time. In order to establish a suitable correlation with other research methodologies, an appropriate scale of 'number of load cycles' was selected in lieu of the 'time' scale (Indraratna et al., 2010). The number of load cycles $(N)$ is determined from the total traffic tonnage $(T)$, axle load $\left(A_{\mathrm{t}}\right)$ and number of axles per load cycle $\left(N_{\mathrm{a}}\right)$ (Selig and Waters, 1994) as given below

$$
\text { 1. } \quad N=\frac{T}{A_{\mathrm{t}} \times N_{\mathrm{a}}}
$$

Delaney (2011) reported a total traffic tonnage of 64 million gross tonnes (MGT) on the third track section during the period of measurement. The majority of traffic was imparted from coal trains having four axles, and axle loads between 25 and $30 \mathrm{t}$. This resulted in $3.3 \times 10^{5}$ load cycles. The results were plotted against the number of load cycles as discussed below.

\subsection{Vertical deformations of ballast}

The deformation of ballast was determined by subtracting the vertical displacement of the ballast-capping interface from that at the sleeper-ballast interface. The mean vertical strain is defined as the ratio of ballast deformation to the initial ballast thickness. Vertical deformation $\left(S_{\mathrm{v}}\right)$ and strains $\left(\varepsilon_{\mathrm{v}}\right)$ of the ballast 
(a) Geogrids and geocomposite

\begin{tabular}{|c|c|c|c|c|c|}
\hline & Geogrid 1 & Geogrid 2 & Geogrid 3 & \multicolumn{2}{|c|}{ Geocomposite } \\
\hline \multicolumn{6}{|l|}{ Physical characteristics } \\
\hline Material & \multicolumn{3}{|c|}{ Polypropylene } & \multicolumn{2}{|c|}{ Polypropylene } \\
\hline Type & Biaxial & Biaxial & Biaxial & $\begin{array}{l}\text { (Grid) } \\
\text { biaxial }\end{array}$ & $\begin{array}{c}\text { (Fabric) } \\
\text { non-woven }\end{array}$ \\
\hline \multicolumn{6}{|l|}{ Technical characteristics } \\
\hline Tensile stiffness ${ }^{a}: M N / m$ & $1 \cdot 8 / 1 \cdot 8$ & $1 \cdot 5 / 1 \cdot 5$ & $1 \cdot 5 / 1 \cdot 5$ & $2 \cdot 0 / 2 \cdot 0$ & $0 \cdot 3 / 0 \cdot 5$ \\
\hline Tensile strengtha ${ }^{a}$ kN/m & $36 / 36$ & $30 / 30$ & $30 / 30$ & $40 / 40$ & $6 / 10$ \\
\hline Strain at break ${ }^{a}: \%$ & $15 / 15$ & $15 / 15$ & $15 / 15$ & $15 / 15$ & $60 / 40$ \\
\hline \multicolumn{6}{|l|}{ Dimensional characteristics } \\
\hline Aperture size $\mathrm{e}^{\mathrm{a}}: \mathrm{mm}$ & $44 / 44$ & $65 / 65$ & $40 / 40$ & $31 / 31$ & - \\
\hline Thickness: mm & 3 & 3 & 4 & 3 & $2 \cdot 9$ \\
\hline Specific mass: $\mathrm{g} / \mathrm{m}^{2}$ & - & - & - & - & 150 \\
\hline
\end{tabular}

(b) Shock mat (UBM)

Physical characteristics

\begin{tabular}{lc}
\hline Material & \multicolumn{2}{c}{ Polyurethane elastomer } \\
\cline { 2 - 2 } Type & Bonded rubber granulates \\
\hline Particle size: $\mathrm{mm}$ & $1-3$ \\
Technical characteristics & 600 \\
Tensile strength: $\mathrm{kN} / \mathrm{m}^{2}$ & 80 \\
Strain at break: \% & \\
Dimensional characteristics & 10 \\
Thickness: $\mathrm{mm}$ &
\end{tabular}

a Values are given as MD/CMD, where MD is the machine direction (longitudinal to the roll) and CMD is the cross-machine direction (across roll width).

Table 2. Properties of (a) geogrids and geocomposite and (b) shock mat (UBM)

layer were plotted against the number of load cycles $(N)$ as shown in Figure 5(a) and (b). The vertical deformation of the ballast was highly non-linear under cyclic loading, as also shown in previous studies (Indraratna et al., 2007, 2010; Indraratna and Nimbalkar, 2013; Jeffs and Marich, 1987; Lackenby et al., 2007). A rapid increase in vertical deformation was observed during the first 200000 load cycles, beyond which the deformation showed only a marginal increase. The zone during which the rate of deformation diminished to a controlled steady state after a certain level of load repetitions had passed, is defined as the 'stable' zone (Figure 5(a) and (b)). When the results for sections on similar subgrades were compared, the vertical deformation of ballast with geosynthetics was $10-32 \%$ smaller than that without reinforcement
(Figure 5(a)). This trend was observed also in the laboratory (Brown et al., 2007), and is mainly attributed to the interlocking between ballast particles and the grid apertures, thus creating an enhanced track confinement.

When the results for sections with similar geogrids (i.e. section 3 and section 5) were compared, it was observed that the effectiveness of a geogrid to reduce track settlement became higher for softer subgrades (Figure 5(a) and (b)). This observation is in agreement with the results of full-scale tests presented by Ashmawy and Bourdeau (1995). It was also observed that among the four types of geosynthetic used, the geogrid at section 3 performed most effectively. Although the tensile strength of this 


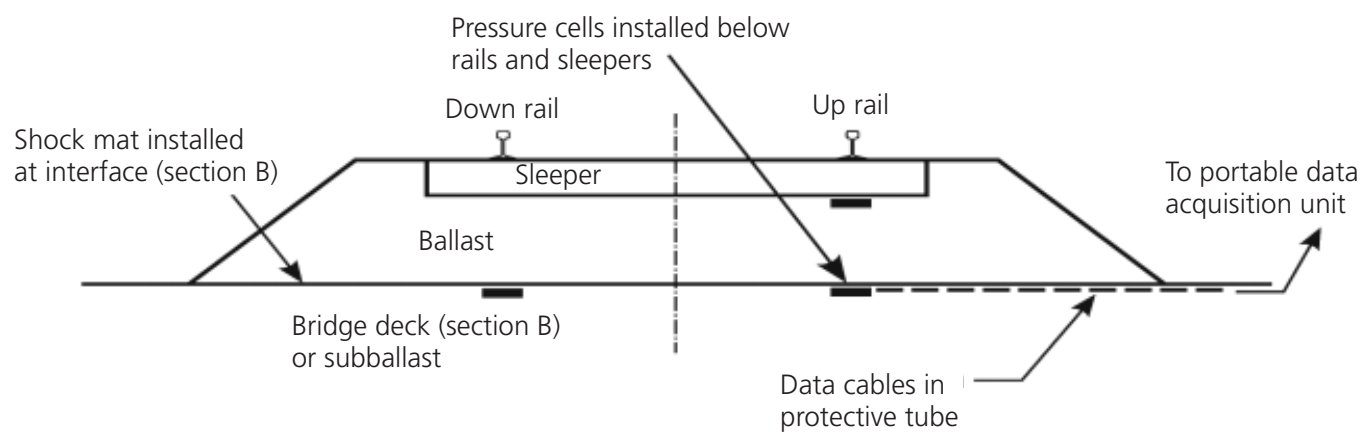

(a)

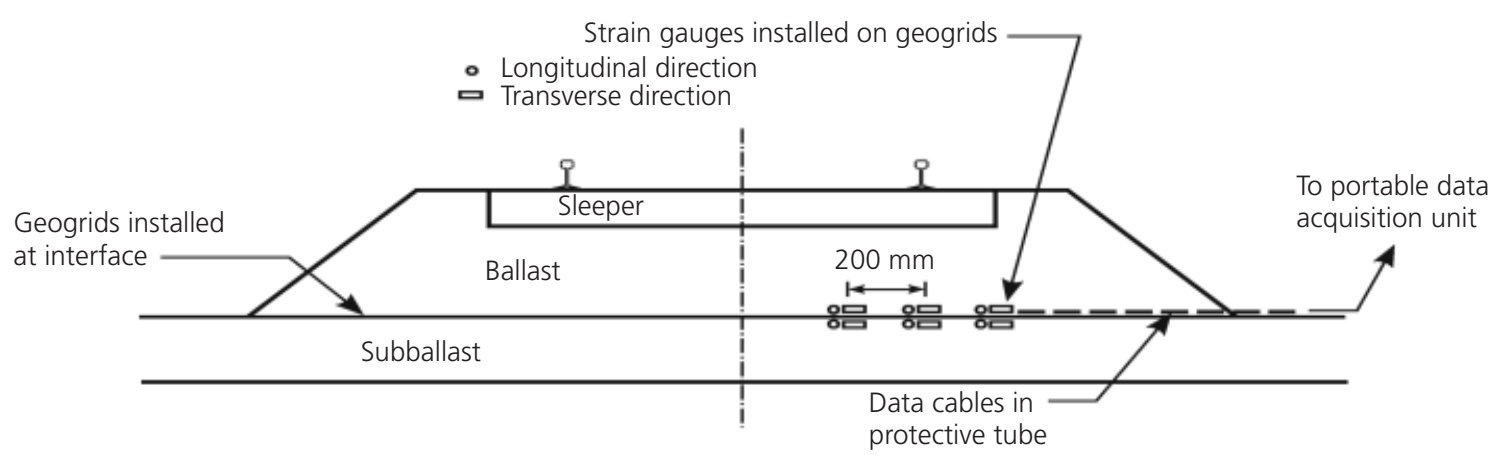

(b)

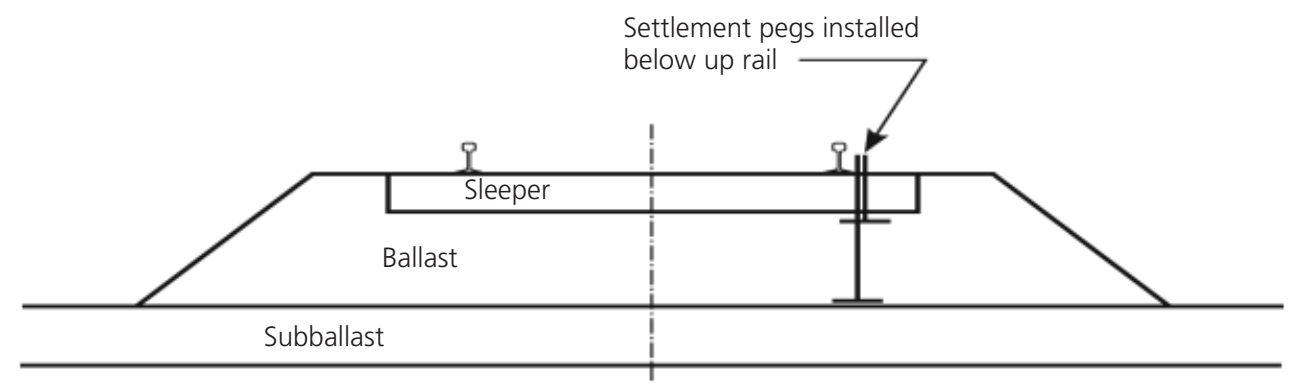

(c)

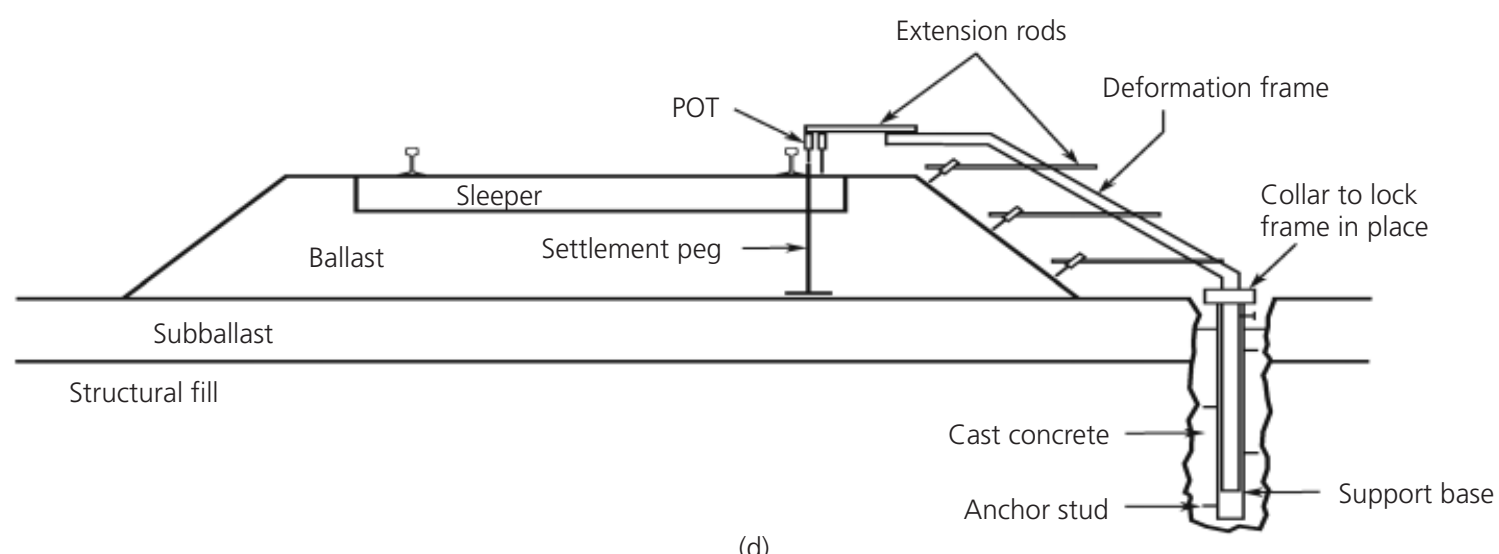

(d)

Figure 4. Details of track instrumentation using (a) pressure cells,

(b) strain gauges, (c) settlement pegs and (d) potentiometers

(POTs) mounted on deformation frame 


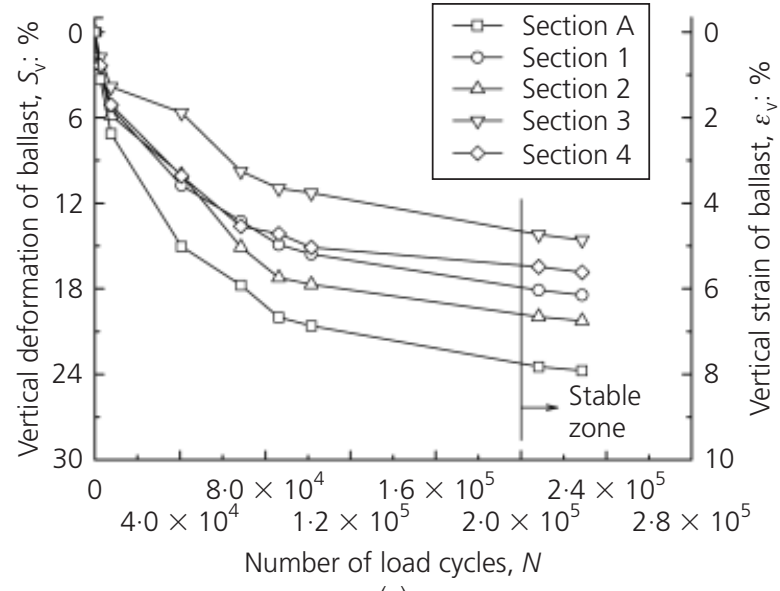

(a)

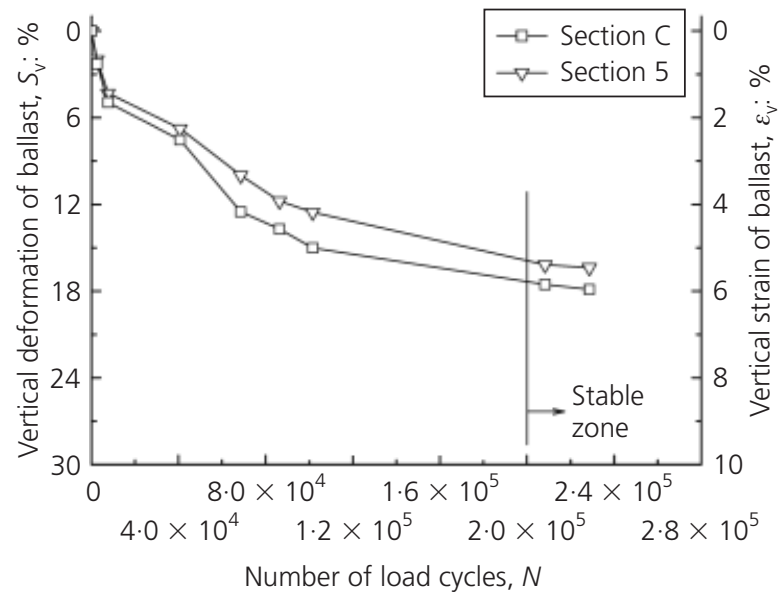

(b)

Figure 5. Vertical deformations and strains of ballast layer plotted against number of load cycles for (a) soft embankment and (b) hard rock

geogrid was not more than that of the others, its aperture size (a) of $40 \mathrm{~mm}$ would enable better interlocking between the ballast and grid. This finding also agrees well with the criteria for optimum aperture sizes for reinforcing geogrids proposed in earlier studies (Brown et al., 2007; Indraratna et al., 2011a).

Usually, the non-linear variation of ballast deformation against the number of load applications is best described by a semilogarithmic relationship (Indraratna and Salim, 2003) such as

$$
\text { 2. } S_{\mathrm{v}}=a^{\prime}+b^{\prime}(\ln N)
$$

where $a^{\prime}$ and $b^{\prime}$ are two empirical constants, depending on the type of ballast, type of geosynthetics used and the initial placement density. Similarly, the relationship between the vertical strain of ballast and the logarithm of load cycles can be expressed by Indraratna et al., $2011 \mathrm{~b}$
3. $\varepsilon_{\mathrm{v}}=c^{\prime}+d^{\prime}(\ln N)$

where $c^{\prime}$ and $d^{\prime}$ are two empirical constants. The non-linear variation of ballast deformation and strains with increasing load cycles becomes linear in the semi-logarithmic plot (Figure 6(a) and (b)). The values of empirical constants were obtained by performing a linear regression analysis as shown in Figure 6(a) and (b). It is observed that Equations 2 and 3 fit the vertical deformations and strains of ballast reasonably well for a wide range of numbers of load cycles.

\subsection{Transient deformation of ballast}

Transient deformation of the ballast layer was measured by the custom-made deformation frame. It was observed that the passage of trains travelling at $40 \mathrm{~km} / \mathrm{h}$ resulted in vertical deformations $\left(S_{\mathrm{tv}}\right)$ of the ballast layer in the range of 1.5 to $3.0 \mathrm{~mm}$ resulting in average vertical strains $\left(\varepsilon_{\mathrm{tv}}\right)$ between 0.5 and $1.0 \%$. The transient horizontal deformation $\left(S_{\mathrm{th}}\right)$ of ballast was always expansive and in the range -0.5 to $-0.3 \mathrm{~mm}$. This resulted in average horizontal strains $\left(\varepsilon_{\text {th }}\right)$ of -0.05 to $-0.02 \%$. The horizontal

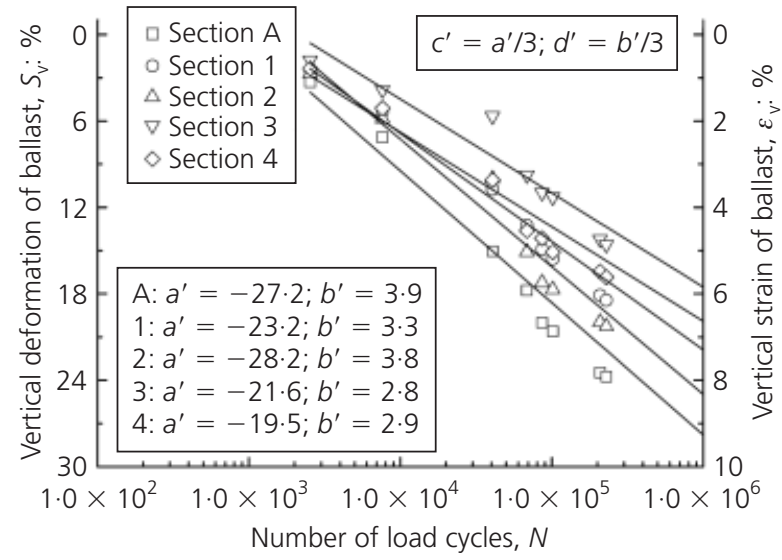

(a)

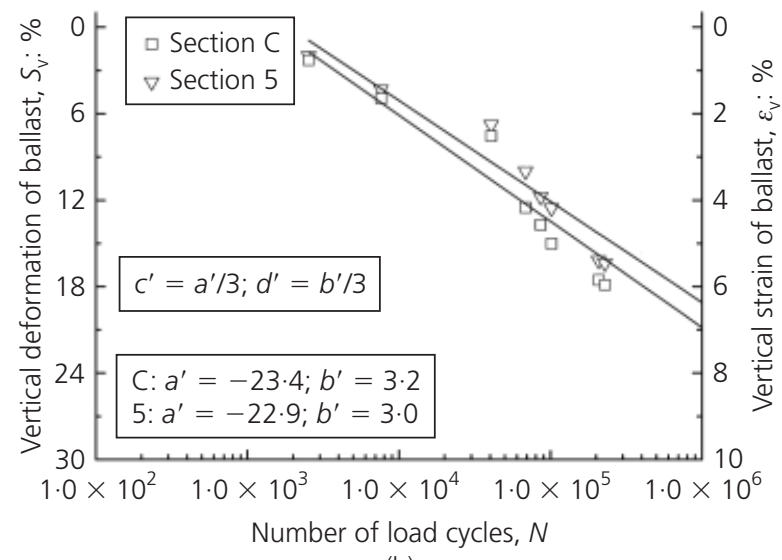

(b)

Figure 6. Vertical deformations and strains of ballast layer plotted in semi-logarithmic scale for (a) soft embankment and (b) hard rock 
strains were larger near the crest and smaller near the toe of the ballast layer. The transient strains $\left(\varepsilon_{\mathrm{tv}}, \varepsilon_{\mathrm{th}}\right)$ of track sections with reinforcement were about $15 \%$ smaller than those without reinforcement regardless of the type of geosynthetics employed.

\subsection{Strains mobilised in geogrids}

Accumulated transverse $\left(\varepsilon_{\mathrm{gt}}\right)$ and longitudinal $\left(\varepsilon_{\mathrm{gl}}\right)$ strains measured from the strain gauges below the edges of sleepers are plotted in Figure 7(a) and (b). The results indicate that both transverse $\left(\varepsilon_{\mathrm{gt}}\right)$ and longitudinal $\left(\varepsilon_{\mathrm{gl}}\right)$ strains generally increased with the number of load cycles, suggesting the accumulation of permanent deformation in the geogrids. It should be highlighted that the majority of strains in both directions probably took place during the construction of the experimental sections, particularly when the ballast was placed. The transverse strains were generally larger than the longitudinal strains. This is attributed to the relative ease for lateral spreading of the track substructure caused by smaller track restraints in the transverse direction. As shown in Figure 7(a), the strains of geocomposite (section 4) were relatively large. This is because the thick general fill at this

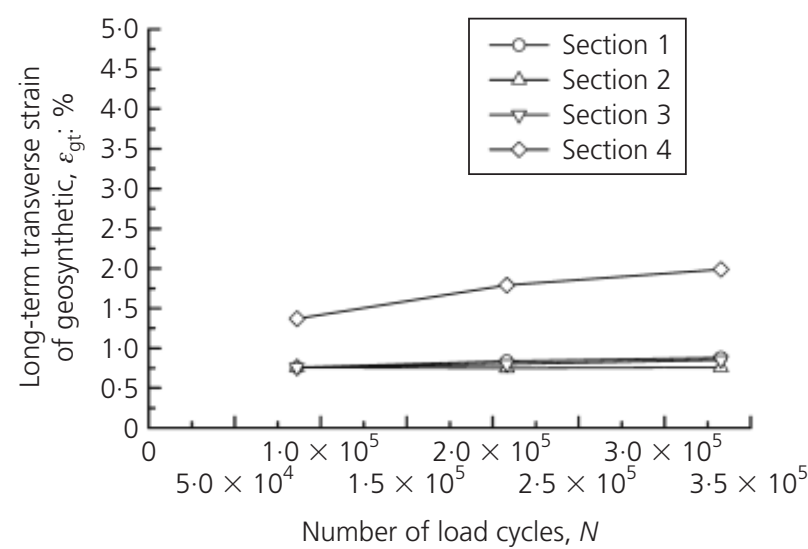

(a)

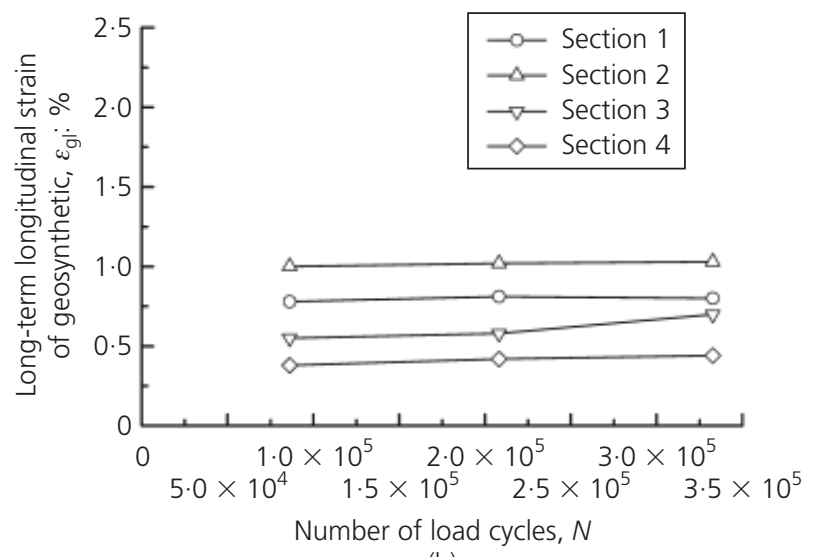

(b)

Figure 7. Strains accumulated in geogrids and geocomposite in (a) transverse and (b) longitudinal directions plotted against number of load cycles location underwent large lateral deformations shortly after track commissioning, resulting in excessive transverse strains in the geocomposite.

Induced transient strains in synthetic grids in both longitudinal $\left(\varepsilon_{\mathrm{tl}}\right)$ and transverse $\left(\varepsilon_{\mathrm{tt}}\right)$ directions due to the passage of trains at a speed of $40 \mathrm{~km} / \mathrm{h}$ were of the order of $0 \cdot 14-0 \cdot 17 \%$. Unlike the case of accumulated strains, smaller values of $\varepsilon_{\mathrm{tl}}$ and $\varepsilon_{\mathrm{tt}}$ were observed in grids with higher values of stiffness.

\subsection{Vertical stresses}

The vertical stresses $\left(\sigma_{\mathrm{v}}^{\prime}\right)$ resulting due to the passage of trains travelling at a speed of $40 \mathrm{~km} / \mathrm{h}$ for sections 1 and A were in the range of 170 to $180 \mathrm{kPa}$ and 30 to $35 \mathrm{kPa}$ at the sleeper-ballast and ballast-capping interfaces, respectively. At section $\mathrm{B}$, the vertical stress at the mat-deck interface was about $150 \mathrm{kPa}$. The vertical stresses for sections 5 and $\mathrm{C}$ were in the range of 215 to $230 \mathrm{kPa}$ and 90 to $110 \mathrm{kPa}$ at the sleeper-ballast and ballastcapping interfaces, respectively. As anticipated, the stresses measured at the sleeper-ballast interface were larger than those at the ballast-capping interface. These results indicate that the induced stresses were considerably larger in a track with stiffer subgrade; that is, the stresses were highest at section B (concrete deck) and lowest at sections $\mathrm{A}$ and 1 (silty clay deposit).

\subsection{Ballast breakage}

Digital photographs of the track formation condition prior to excavation were taken together with a photograph of the sampling pit (Figure 8(a)). Samples were recovered from beneath the sleeper and the rail seat. This sampling location was considered to be most appropriate, as vertical stresses are usually the largest beneath the rail seat (Indraratna et al., 2010; Indraratna and Nimbalkar, 2013). Samples were collected from three equal portions of load-bearing ballast in order to assess the variation of ballast breakage with depth as shown in Figure 8(a). The ballast profile was then reinstated using clean ballast and tamped using a tamping head on the excavator. Visual inspection of the samples showed no apparent foreign materials in the ballast. Only rock fragments, which most likely resulted from particle breakage, were found in these ballast samples. This suggested that fouling of the ballast layer due to spillage of coal from passing trains and 'slurry pumping' of the fines from the underlying subgrade had not taken place on this section of the relatively new track.

The breakage is quantified using the parameter, ballast breakage index (BBI), proposed by Indraratna et al. (2005). By utilising a linear hypothetical size axis as reference, BBI is calculated using Equation 4

$$
\text { 4. } \mathrm{BBI}=\frac{A}{A+B}
$$

where $A$ is shift in the particle size distribution (PSD) curve due to breakage; and $B$ is the potential breakage or the area between 


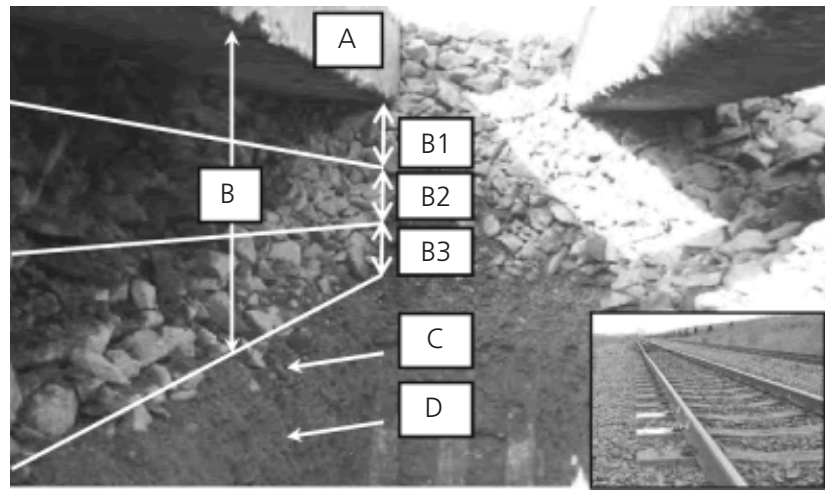

(a)

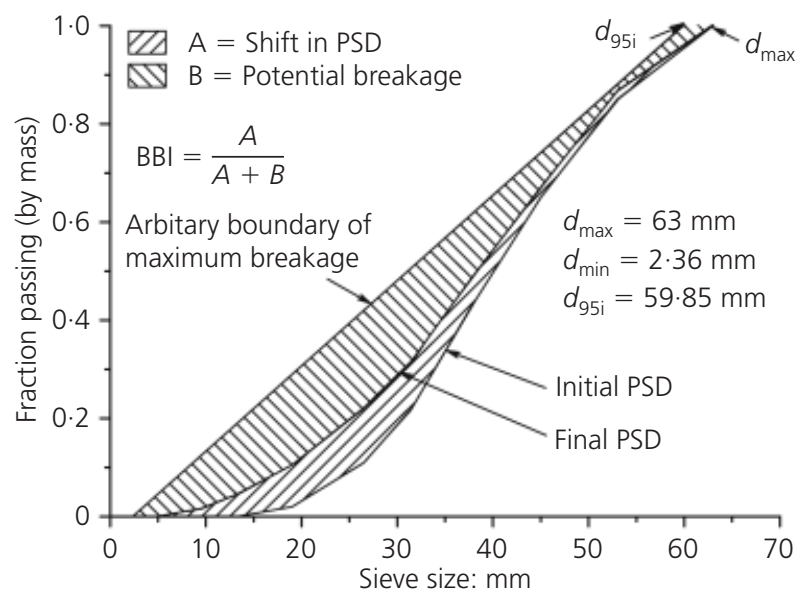

(b)

Figure 8. (a) Photograph showing sampling pit for ballast breakage assessment: A, sleeper; B, ballast; B1, top zone; B2, central zone; B3, bottom zone; C, capping; D, structural-fill. (b) Determination of ballast breakage index (data sourced from Indraratna et al. (2005))

the arbitrary boundary of maximum breakage and the final PSD. The parameters $A$ and $B$ are obtained as defined in Figure $8(\mathrm{~b})$. The values of BBI after $7 \cdot 8 \times 10^{5}$ load cycles are shown in Table 3. As expected, the ballast breakage was highest at the top and decreased with the increase in depth. Although the typical train speeds of sections A and B were practically similar, the smaller shear or deviator stresses imparted on the ballast due to larger lateral confinement from the barriers of Mudies Creek bridge most likely resulted in a significantly smaller value of BBI at section B. These results may also suggest the effectiveness of UBMs in reducing ballast degradation when placed above the concrete deck. However, sufficient data from a similar bridge without any UBM are necessary for more convincing validation.

\section{Conclusions}

A comprehensive field monitoring programme was undertaken on instrumented track sections to study the effectiveness of various geosynthetics at improving the overall stability of ballasted rail tracks. Four types of geosynthetics with different geometrical and mechanical properties were installed at the ballast-capping interface. The experimental track sections were located on three types of subgrades. It was found that geogrids and geocomposite could decrease vertical deformations of the ballast by as much as $35 \%$, with obvious benefits of improved track stability and decreased maintenance cost. For the biaxial geogrids and geocomposite employed, the aperture sizes of the geogrids which resulted in least ballast deformations (both long-term and transient) were in the range of $1 \cdot 1 d_{50}$.

The effectiveness of reinforcement increased in the case of softer subgrade. Transient strains of the ballast layer also decreased when geosynthetics were used. The traffic-induced vertical stresses at the ballast-capping interface were larger on stiffer subgrades. The reduced ballast breakage at the concrete bridge was found to be associated with the increased lateral track confinement. The use of shock mat (UBM) also reduces ballast breakage. However, this needs further validation through collection of more field data from a similar bridge without any UBM. The findings of this field study allow for better assessment of the performance of geosynthetic reinforcement and energy-absorbing UBMs to mitigate track degradation caused by cyclic and impact wheel loads. Better understanding of such performance would allow for safer and more effective design and analysis of ballasted rail tracks with geosynthetic reinforcement.

\section{Acknowledgements}

The authors are grateful to the CRC for Rail Innovation (established and supported under the Australian Government's Cooperative Research Centres programme) for the funding of
Serial Section details and subgrade conditions no.
Ballast breakage index (BBI)

\begin{tabular}{ccc}
\hline $\begin{array}{c}\text { Top zone } \\
100 \mathrm{~mm} \text { thick }\end{array}$ & $\begin{array}{c}\text { Central zone } \\
100 \mathrm{~mm} \text { thick }\end{array}$ & $\begin{array}{c}\text { Bottom zone } \\
100 \mathrm{~mm} \text { thick }\end{array}$ \\
0.17 & 0.078 & 0.064 \\
0.064 & 0.031 & 0.022
\end{tabular}

1 Section A (relatively soft general fill and alluvial silty clay deposit)

2 Section B (stiff reinforced concrete bridge deck)

Table 3. Assessment of ballast breakage resulted from train traffic during the period of measurements ( $\mathrm{N}=7 \cdot 8 \times 10^{5} \mathrm{load}$ cycles) 
this research project R3.117 entitled 'Track design and analysis for impact and cyclic loads - Singleton field study'. They would also like to thank the Industry partners including RailCorp, ARTC and QR National Limited for their keen collaboration in this study. The assistance of Dr Pongpipat Anantanasakul (Lecturer, Mahidol University, Thailand) during his stay at University of Wollongong as a part of his postdoctoral research programme is gratefully acknowledged. The authors would also like to thank Alan Grant, Cameron Neilson and Ian Bridge of the University of Wollongong for their technical support during this study. The on-site assistance provided by Carol Bolam, Tony Miller and Darren Mosman of Hunt8r Alliance (Newcastle) and David Williams of ARTC (Newcastle) is appreciated.

\section{REFERENCES}

Anastasopoulos I, Alfi S, Gazetas G et al. (2009) Numerical and experimental assessment of advanced concepts to reduce noise and vibration on urban railway turnouts. Journal of Transportation Engineering ASCE 135(5): 279287.

ARTC (Australian Rail Track Corporation) (2006a) RCP-01: Standard for Earthworks Construction Procedures. Australian Rail Track Corporation, Newcastle, NSW, Australia.

ARTC (2006b) TDS-12: Standard for Formation Capping Material. Australian Rail Track Corporation, Newcastle, NSW, Australia.

ARTC (2007a) ETA-04-01: Ballast Specifications. Australian Rail Track Corporation, Newcastle, NSW, Australia.

ARTC (2007b) TDS-08: General Standards for Formation and Earthworks. Australian Rail Track Corporation, Newcastle, NSW, Australia.

Ashmawy AK and Bourdeau PL (1995) Geosynthetic-reinforced soils under repeated loading: a review and comparative design study. Geosynthetics International 2(4): 643-678.

Auersch L (2006) Dynamic axle loads on tracks with and without ballast mats: numerical results of three-dimensional vehicletrack-soil models. Proceedings of the Institution of Mechanical Engineers, Part F: Journal of Rail and Rapid Transit 220(2): 169-183.

Brown SF, Kwan J and Thom NH (2007) Identifying the key parameters that influence geogrid reinforcement of railway ballast. Geotextiles and Geomembranes 25(6): 326-335.

Chen C, McDowell GR and Thom NH (2012) Discrete element modelling of cyclic loads of geogrid-reinforced ballast under confined and unconfined conditions. Geotextiles and Geomembranes 35(12): 76-86.

Delaney M (2011) Geotechnical Investigation of Specific Areas of Track Formation Concern for Minimbah Bank Stage 1 Third Track. Newcastle Geotech, NSW, Australia. Report 138 4Rev1, pp. 1-143.

Esveld C (2009) The significance of track resilience. European Rail Review Digital News Issue. Russell Publishing Limited, London, UK, pp. 14-20.

Ferreira PA and López-Pita A (2013) Numerical modeling of high-speed train/track system to assess track vibrations and settlement prediction. Journal of Transportation Engineering ASCE 139(3): 330-337.

Indraratna B and Nimbalkar S (2013) Stress-strain degradation response of railway ballast stabilized with geosynthetics. Journal of Geotechnical and Geoenvironmental Engineering ASCE 139(5): 684-700.

Indraratna B and Salim W (2003) Deformation and degradation mechanics of recycled ballast stabilised with geosynthetics. Soils and Foundations 43(4): 35-46.

Indraratna B, Lackenby J and Christie D (2005) Effect of confining pressure in the degradation of ballast under cyclic loading. Géotechnique 55(4): 325-328.

Indraratna B, Shahin MA and Salim W (2007) Stabilisation of granular media and formation soil using geosynthetics with special reference to railway engineering. Ground Improvement 11(1): 27-43.

Indraratna B, Nimbalkar S, Christie D et al. (2010) Field assessment of the performance of a ballasted rail track with and without geosynthetics. Journal of Geotechnical and Geoenvironmental Engineering ASCE 136(7): 907-917.

Indraratna B, Hussaini SK and Vinod JS (2011a) On the shear behaviour of ballast-geosynthetic interfaces. Geotechnical Testing Journal ASTM 35(2): 1-8.

Indraratna B, Salim W and Rujikiatkamjorn C (2011b) Advanced Rail Geotechnology - Ballasted Track. CRC Press/Balkema, Leiden, the Netherlands.

Indraratna B, Nimbalkar S and Rujikiatkamjorn C (2012) Track stabilisation with geosynthetics and geodrains, and performance verification through field monitoring and numerical modeling. International Journal of Railway Technology 1(1): 195-219.

Jeffs T and Marich S (1987) Ballast characteristics in the laboratory. Proceedings of a Conference on Railway Engineering, Perth, Australia, pp. 141-147.

Lackenby J, Indraratna B, McDowel GR et al. (2007) Effect of confining pressure on ballast degradatoin and deformation under cyclic triaxial loading. Géotechnique 57(6): 527-536.

McDowell GR and Harireche O (2002) Discrete element modelling of soil particle fracture. Géotechnique 52(2): 131135 .

McDowell GR, Harireche O, Konietzky H et al. (2006) Discrete element modelling of geogrid-reinforced aggregates. Proceedings of the Institution of Civil Engineers Geotechnical Engineering 159(1): 35-48.

Nimbalkar S, Indraratna B, Dash SK et al. (2012) Improved performance of railway ballast under impact loads using shock mats. Journal of Geotechnical and Geoenvironmental Engineering ASCE 138(3): 281-294.

Railtrack (Railtrack Line Specification) (2000) RT-CE-S-006: Track Ballast. Railtrack, London, UK.

RCA (2008) Geotechnical Investigation Report for Minimbah Bank Third Track. RCA Australia, Newcastle, NSW, Australia.

Rowe PK and Jones CP (2000) Geosynthetics: innovative 
materials and rational design. Proceedings of GEOENG 2000, Melbourne, Australia, pp. 1124-1156.

Selig ET and Waters JM (1994) Track Geotechnology and

Substructure Management. Thomas Telford, London, UK. Shin EC, Kim DH and Das BM (2002) Geogrid-reinforced railroad bed settlement due to cyclic load. Geotechnical and Geological Engineering 20(3): 261-271.

Standards Australia (1996) AS 2758. 7: Aggregates and rock for engineering purposes. Standards Australia, Sydney, NSW, Australia.
WHAT DO YOU THINK?

To discuss this paper, please email up to 500 words to the editor at journals@ice.org.uk. Your contribution will be forwarded to the author(s) for a reply and, if considered appropriate by the editorial panel, will be published as a discussion in a future issue of the journal.

Proceedings journals rely entirely on contributions sent in by civil engineering professionals, academics and students. Papers should be 2000-5000 words long (briefing papers should be 1000-2000 words long), with adequate illustrations and references. You can submit your paper online via www.icevirtuallibrary.com/content/journals, where you will also find detailed author guidelines. 